\title{
Analisis Pengaruh Penambahan Durasi Camshaft terhadap Unjuk Kerja dan Emisi Gas Buang pada Engine Sinjai $650 \mathrm{cc}$
}

\author{
Firman Iffah Darmawangsa dan Bambang Sudarmanta \\ Jurusan Teknik Mesin, Fakultas Teknologi Industri, Institut Teknologi Sepuluh Nopember Surabaya \\ Jl. Arief Rahman Hakim, Surabaya 60111 Indonesia \\ e-mail:sudarmanta@me.its.ac.id
}

\begin{abstract}
Abstrak-Pengembangan industri otomotif mengarah pada jaminan kenyamanan saat dikendarai dengan menghasilkan unjuk kerja yang tinggi, konsumsi bahan bakar rendah, getaran dan emisi gas buang yang rendah. Salah satu parameter yang mempengaruhi adalah besarnya pasokan udara pembakaran kedalam ruang bakar. Dimana hal ini diatur oleh mekanisme camshaft melalui buka-tutup katup pemasukan dan katup pembuangan. Penelitian ini ingin mengetahui pengaruh penambahan durasi camshaft terhadap unjuk kerja engine utamanya pada putaran tinggi. Penelitian ini dilakukan pada engine 4 langkah 2 silinder SINJAI 650cc Single Overhead Camshaft (SOHC) sistem Port Injection dengan fokus pengoperasian pada putaran tinggi. Variasi durasi akan dilakukan pada kedua cam, yakni cam katup masuk dan cam katup buang. Dimana variasi durasi akan dibagi menjadi $\mathbf{2 4 8}^{\circ}$

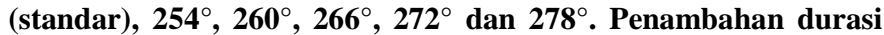
dilakukan secara simetris $3^{\circ}$ poros engkol sebelum katup membuka dan setelah katup menutup sehingga tidak ada perubahan pada Lobe Separation Angel (LSA). Metode penelitian ini menggunakan dua tahapan, metode simulasi kemudian metode eksperimen. Untuk mengetahui pengaruh dari variasi durasi camshaft terhadap unjuk kerja engine, terlebih dahulu akan dilakukan simulasi menggunakan software LOTUS Engine Simulation (LES). Dari hasil simulasi menggunakan LOTUS Engine Simulation pada engine SINJAI 650 ce SOHC port injection, diperoleh durasi camshaft terbaik $260^{\circ}$ pada putaran tinggi. Dengan peningkatan torsi $0.908 \%$, daya $0.908 \%$, bmep $0.908 \%$, efisiensi thermal $0.626 \%$, efisiensi volumetris $1.003 \%$ dan penurunan bsfe $0.252 \%$, dari camshaft standar $248^{\circ}$ pada putaran tinggi. Menurut hasil eksperimen, perbandingan unjuk kerja dari durasi camshaft $248^{\circ}$ dan $260^{\circ}$, terjadi peningkatan torsi $5.53 \%$, daya $5.53 \%$, bmep $5.53 \%$, efisiensi thermal $14.58 \%$, efisiensi volumetris $2.04 \%$ dan penurunan bsfc $17.905 \%$, emisi CO 5.183\%, serta emisi HC 7.578\%.
\end{abstract}

Kata kunci-durasi camshaft, putaran tinggi, lotus engine simulation, sinjai, sohc.

\section{PENDAHULUAN}

$\mathrm{E}$ FISIENSI thermal pada engine saat ini telah diketahui berkisar antara 32\% hingga 35\% [1]. Kerugian panas diantaranya kerugian pembakaran nyata (panas spesifik dan dissosiasi), kerugian blow-by, kerugian pendinginan (kerugian panas langsung), kerugian pertukaran gas (pembakaran tidak sempurna), kerugian gesekan dan kerugian lainnya [2]. Faktor yang juga mempengaruhi unjuk kerja engine dan mengurangi emisi gas buang adalah kualitas pembakaran bahan bakar didalam ruang bakar [3]. Salah satu parameter yang mempengaruhi adalah besarnya pasokan udara pembakaran kedalam ruang bakar. Dimana pasokan ini diatur oleh mekanisme camshaft melalui buka-tutup katup pemasukan dan katup pembuangan.

Peran dari camshaft sangatlah penting, diantaranya sebagai menentukan waktu pembukaan katup, mengatur lamanya durasi pembukaan katup, menentukan lamanya durasi overlap katup masuk dan katup buang, serta merupakan komponen utama dari mekanisme valve-train. Penelitian ini ingin mengetahui pengaruh penambahan durasi camshaft terhadap unjuk kerja engine utamanya pada putaran tinggi.

Mendesain ulang camshaft standar diharapkan mampu meningkatkan efisiensi volumetris udara yang masuk ke ruang bakar dan meningkatkan tekanan kompresi di ruang bakar sehingga dapat memperbaiki kualitas pembakaran didalam ruang bakar. Kualitas pembakaran yang lebih baik dapat meningkatkan unjuk kerja dan emisi gas buang menurun. Desain camshaft yang sesuai dengan spesifikasi engine, menghasilkan unjuk kerja yang terbaik dariengine tersebut.

Berdasarkan uraian diatas, maka akan dilakukan analisis variasi durasi camshaft terhadap unjuk kerja dan emisi gas buang saat putaran tinggi pada engine 4 langkah 2 silinder SINJAI 650cc SOHC sistem Port Injection. Variasi durasi dibagi menjadi $248^{\circ}$ (standar), $254^{\circ}, 260^{\circ}, 266^{\circ}, 272^{\circ}$ dan $278^{\circ}$. Penambahan durasi dilakukan secara simetris $3^{\circ}$ poros engkol sebelum katup membuka dan setelah katup menutup. Untuk penelitian ini tidak ada perubahan pada LSA. Terlebih dahulu akan dilakukan simulasi menggunakan software LOTUS Engine Simulation. Parameter unjuk kerja yang diukur dan dibandingkan yaitu daya, torsi, konsumsi bahan bakar, debit udara masuk, serta temperatur operasional.

Variasi durasi camshaft yang menunjukkan hasil unjuk kerja terbaik akan difabrikasi dan diaplikasikan pada engine SINJAI 650cc SOHC port injection, selanjutnya pengujian eksperimental untuk membandingkan hasil unjuk kerja camshaft standar dengan camshaft terbaik hasil dari simulasi software LOTUS Engine Simulation.

\section{TINJAUAN PUSTAKA}

\section{A. Cara Kerja Camshaft}

Waktu pembukaan katup pada siklus ideal yaitu pada saat dimana piston di titik mati atas ataupun bawah, namun beberapa halangan menyebabkan mereka tidak mungkin membuka pada saat-saat tersebut, namun harus dibuka atau 
ditutup sebelum dan sesudah titik mati. Ada dua faktor utama yang menyebabkan yaitu mekanikal dan dinamikal [2].

Faktor mekanikal, katup-katup dibuka dan ditutup oleh mekanisme cam yang mana disana terdapat celah antara cam, tappet dan katup yang harus diangkat secara perlahan untuk menghindarkan keausan dan suara berisik, dengan alas an yang sama katup tidak boleh ditutup secara mendadak, atau akan terjadi bouncing, sehingga bentuk dari kontur harus sedemikian rupa sehingga tidak terjadi bouncing. Terbuka dan tertutupnya katup membutuhkan derajat engkol yang lebih lama dari yang disediakan $90^{\circ}$, yaitu sekian derajat sebelum dan sekian derajat sesudah titik mati. Ini berlaku baik untuk katup masuk maupun katup buang.

Faktor dinamikal, selain masalah mekanikal untuk membuka dan menutup katup maka yang diperhatikan disini adalah akibat aliran dinamik gas yang terjadi pada katup.

\section{METODOLOGI PENELITIAN}

\section{A. Engine yang Digunakan}

Berikut spesifikasi dasar engine SINJAI 650 cc yang akan menjadi acuan dalam proses penelitian:

Tabel.1

Spesifikasi Engine SINJAI $650 \mathrm{cc}$

\begin{tabular}{|l|l|}
\hline Model & SINJAI 650 cc \\
\hline Tipe Kepala Silinder & SOHC 2 valve \\
\hline Sistem Pemasukan BB & Port Injection (for SOHC) \\
\hline Jumlah Silinder & 2 Silinder, Segaris \\
\hline Pendingin Engine & Pendingin Cairan \\
\hline Diameter x Langkah & 76 x 71 mm \\
\hline Rasio Kompresi & $9,0: 1$ (for SOHC) \\
\hline Daya Maksimum SOHC & $28 \mathrm{~kW} / 5000 \mathrm{rpm}$ \\
\hline Torsi Maksimum SOHC & 49 N.m/3300 rpm \\
\hline Putaran Idle & $900 \pm 50 \mathrm{rpm}$ \\
\hline Katup Masuk Membuka & $25^{\circ}$ sebelum TMA \\
\hline Katup Masuk Menutup & $43^{\circ}$ setelah TMB \\
\hline Katup Buang Membuka & $53^{\circ}$ sebelum TMB \\
\hline Katup Buang Menutup & $15^{\circ}$ setelah TMA \\
\hline
\end{tabular}

\section{B. Pengujian dengan Metode Simulasi}

Pada pemodelan dengan LOTUS Engine Simulation, yang pertama kali dilakukan adalah dengan memasukkan sejumlah komponen engine, diantaranya fuel, inlet/outlet, bend \& straight pipe, intake \& exhaust valve port, valve mechanism dan cylinder kedalam main windows. Komponen-komponen tersebut disusun secara seri dan berurutan mulai dari inlet hingga outlet, serta tidak lupa menginputkan dimensi yang telah diukur sebelumnya. Seperti ditunjukkan pada Gambar 1.

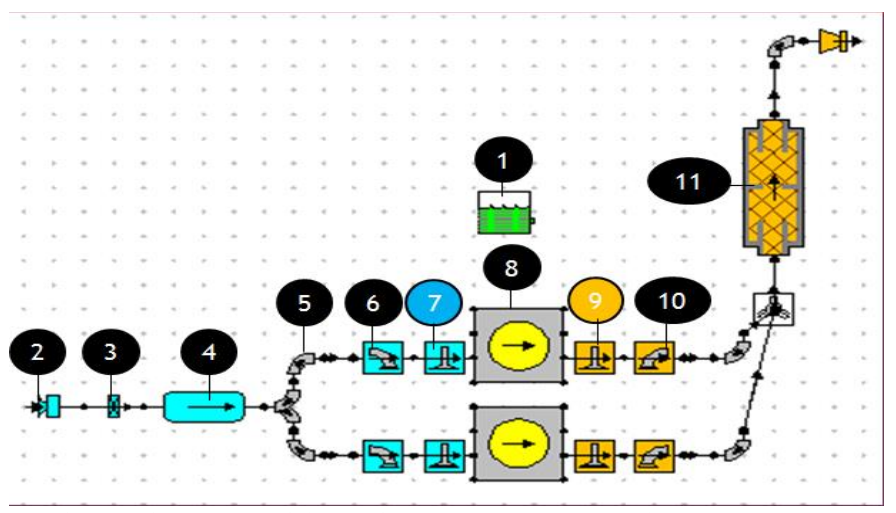

Gambar 1. Skema pemodelan pada LOTUS Engine Simulation

1. Memilih komponen bahan bakar pada main windows LOTUS Engine Simulation, kemudian untuk merubah data input dari bahan bakar dipilih fuel type, user defined. Masukkan data input bahan bakar seperti calorific value ( $\mathrm{kj} / \mathrm{kg})$, density ( $\mathrm{kg} / \mathrm{litre}$ ) dan $H / C$ ratio fuel (molar).

Gambar 2. Simbol bahan bakar pada LES

2. Memasukkan komponen default inlet dan exit kedalam main windows LOTUS Engine Simulation, pilih boundary data kemudian memasukkan data input seperti nilai tekanan dan temperature ambient pada setiap putaran engine.

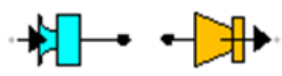

Gambar 3. Simbol default inlet dan exit pada LES

3. Memasukkan komponen intake throttle kedalam main windows LOTUS Engine Simulation, kemudian memilih throttle type yang akan disimulasikan, dalam hal ini digunakan type butterfly, kemudian memasukkan data input seperti throttle diameter ( $\mathrm{mm})$, closed angle (deg), throttle angle (deg) dan pindle diameter $(\mathrm{mm})$.

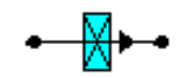

Gambar 4. Simbol intake throttle pada LES

4. Memasukkan komponen intake dan exhaust plenum kedalam main windows LOTUS Engine Simulation, kemudian memasukkan data input seperti volume (litres), surface area $\left(\mathrm{mm}^{2}\right)$ dan wall temperature $\left({ }^{\circ} \mathrm{C}\right)$.

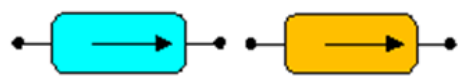

Gambar 5. Simbol intake dan exhaust plenum pada LES

5. Memasukkan komponen bend pipe kedalam main windows LOTUS Engine Simulation, kemudian memasukkan data input seperti total length (mm), start diameter $(\mathrm{mm})$, end diameter $(\mathrm{mm})$, bend angle $(\mathrm{deg})$ dan bend radius (deg).

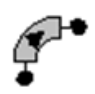

Gambar 6. Simbol bend pipe pada LES 
6. Memasukkan komponen straight pipe kedalam main windows LOTUS Engine Simulation, kemudian memasukkan data input seperti total length $(\mathrm{mm})$, start diameter $(\mathrm{mm})$, end diameter $(\mathrm{mm})$ dan wall material.

Gambar 7. Simbol straight pipe pada LES

7. Memasukkan komponen intake dan exhaust port kedalam main windows LOTUS Engine Simulation, kemudian memasukkan data input seperti throat diameter $(\mathrm{mm})$.

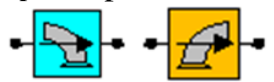

Gambar 8. Simbol intake dan exhaust port pada LES

8. Memasukkan komponen intake dan exhaust valve kedalam main windows LOTUS Engine Simulation, kemudian memasukkan data input seperti valve open (deg), valve close (deg), dwell at max (deg) dan max lift $(\mathrm{mm})$.

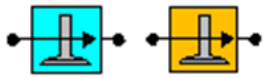

Gambar 9. Simbol intake dan exhaust valve pada LES

9. Memasukkan komponen cylinder kedalam main windows LOTUS Engine Simulation, kemudian memasukkan data input seperti bore $(\mathrm{mm})$, stroke $(\mathrm{mm})$, con-rod length $(\mathrm{mm})$, pin off-set (mm), compression ratio dan combustion model.

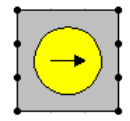

Gambar 10. Simbol cylinder pada LES

10. Untuk memilih data steady state maka dipilih data, test conditions, steady state create wizard. Kemudian memasukkan data inputan seperti ambient air pressure (bar abs), ambient air temperature $\left({ }^{\circ} \mathrm{C}\right)$, inlet pressure (bar abs), inlet temperature $\left({ }^{\circ} \mathrm{C}\right)$, exit pressure (bar abs) dan specific humidity $(\mathrm{kg} / \mathrm{kg})$.

\section{Pengujian dengan Metode Eksperimen}

Percobaan akan dilakukan pada putaran engine yang bervariasi mulai dari $1000 \mathrm{rpm}$ hingga $5000 \mathrm{rpm}$. Pengaturan putaran mesin dilakukan melalui pembebanan elektris yang telah dikopel dengan poros mesin SINJAI dengan menggunakan prinsip eddy current. Berikut adalah langkahlangkah yang akan dilakukan:

1. Menghidupkan mesin pada putaran idle $( \pm 950 \mathrm{rpm})$ selama 10 menit untuk mencapai kondisi steady state atau stasioner.

2. Blower dihidupkan.

3. Membuka katup kupu-kupu hingga terbuka penuh (full open throttle). Pada kondisi ini putaran mesin sebesar $5000 \mathrm{rpm}$ dan merupakan putaran maksimum dari mesin. Selama putaran maksimum, tidak dilakukan pembebanan pada eddy current dynamometer.
4. Pembebanan eddy current dynamometer sehingga putaran mesin berada pada 1000 rpm untuk kemudian dilakukan pengambilan data untuk tiap kelipatan 500 rpm.

5. Jika putaran mesin sudah stabil maka pencatatan data dapat dilakukan meliputi data putaran mesin (rpm), torsi (Lbf.ft), waktu konsumsi $25 \mathrm{ml}$ bahan bakar premium (sekon), selisih ketinggian pada manometer $\mathrm{U}$, emisi $\mathrm{CO}$ (\% volume), emisi $\mathrm{CO}_{2}$ (\% volume), emisi $\mathrm{HC}$ (ppm volume), temperatur gas buang $\left({ }^{\circ} \mathrm{C}\right)$, temperatur head $\left({ }^{\circ} \mathrm{C}\right)$, dan temperatur oli $\left({ }^{\circ} \mathrm{C}\right)$.

6. Pada setiap tahap kenaikan putaran mesin dilakukan pencatatan data seperti pada poin 5 (lima). Dan harus diingat bahwa pencatan data dilakukan pada saat putaran mesin dalam kondisi stabil.

7. Lakukan kegiatan point 1 (satu) sampai 6 (enam) dengan menggunakan camshaft standar dan camshaft terbaik hasil simulasi.

\section{ANALISA DATA DAN PEMBAHASAN}

A. Analisa Grafik Torsi vs Putaran

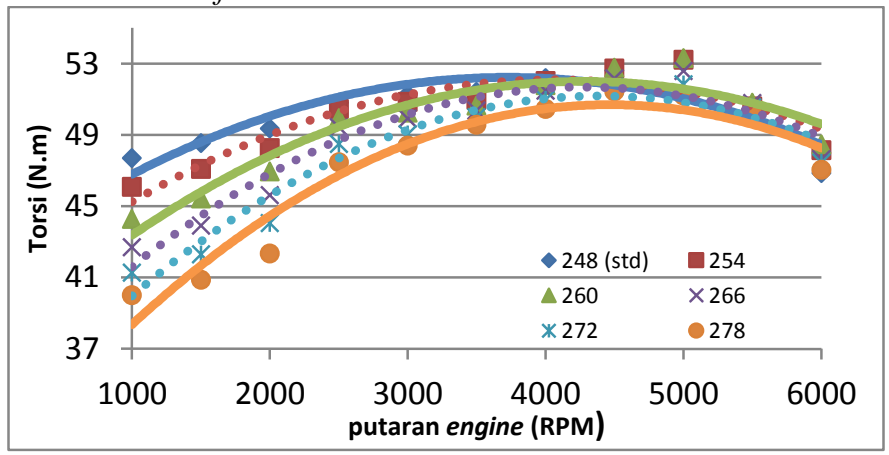

Gambar 11. Grafik Torsi vs rpm hasil simulasi

Dari Gambar 11 dapat dilihat trendline kenaikan torsi terjadi mulai dari putaran engine $1000 \mathrm{rpm}$. Torsi terjadi penurunan pada putaran $4500 \mathrm{rpm}$ pada camshaft durasi $248^{\circ}$ (standar). Sedangkan pada camshaft durasi $254^{\circ}, 260^{\circ} 266^{\circ}$, $272^{\circ}$, dan $278^{\circ}$ torsi terus meningkat hingga putaran engine mencapai $5000 \mathrm{rpm}$. Hal ini menyebabkan terjadinya perbedaan letak puncak torsi pada tiap durasi camshaft. Torsi terbesar pada putaran tinggi terjadi pada camshaft durasi $260^{\circ}$ pada putaran $5000 \mathrm{rpm}$. Dengan camshaft durasi rendah durasi overlap yang kecil mengakibatkan udara masuk ke silinder dengan baik karena tidak banyak udara yang terbuang sia-sia sehingga menghasilkan pembakaran yang baik dan juga menghasilkan torsi besar. Saat putaran engine tinggi laju aliran udara bergerak cepat. Dengan camshaft durasi tinggi, durasi overlap yang besar mengakibatkan proses pembilasan gas sisa pembakaran terjadi dengan baik. Disamping itu proses penginduksian juga terjadi secara cepat dan udara yang masuk lebih banyak pada camshaft durasi tinggi, sehingga menghasilkan pembakaran yang baik dan juga menghasilkan torsi besar pada putaran tinggi. 


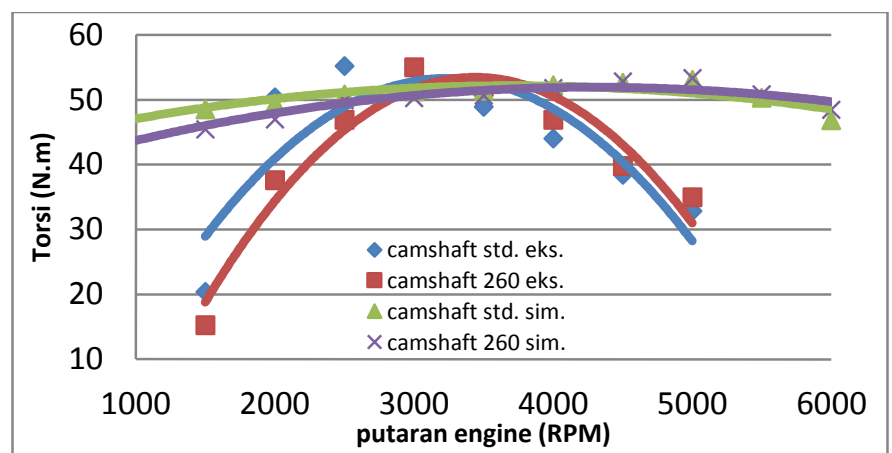

Gambar 12. Grafik Torsi vs rpm hasil simulasi dan eksperimen

Dari Gambar 12 dapat dilihat bahwa terjadi selisih nilai torsi antara hasil eksperimen dengan simulasi. Grafik diatas menunjukkan bahwa simulasi rata-rata menghasilkan torsi yang lebih besar daripada eksperimen. Selain itu dengan memodifikasi camshaft menjadi $248^{\circ}$ akan menghasilkan torsi yang lebih besar pada putaran rendah, namun torsi menurun pada putaran tinggi. Ini terjadi baik pada simulasi maupun eksperimen. Dengan menggunakan camshaft modifikasi terjadi pergeseran puncak torsi yaitu pada $3000 \mathrm{rpm}$. Selisih nilai torsi dari simulasi dan eksperimen disebabkan oleh beberapa faktor, baik dari faktor software simulasi, engine, alat ukur maupun pembacaan alat ukur. Dari faktor software, yaitu karena data input yang diberikan dianggap ideal seperti combustion efficiency $80 \%$, timing heat-phase yang sempurna, air fuel ratio selalu stokiometri, temperatur dan udara luar yang selalu konstan, serta faktor-faktor lainnya. Sedangkan yang kedua dari faktor engine, dimana kondisi engine tersebut tidak $100 \%$ baik karena sudah digunakan untuk pengujianpengujian sebelumnya serta sudah dilakukan proses bongkarpasang dalam jumlah yang banyak. Kondisi tersebut dapat mempengaruhi hasil pengukuran unjuk kerja. Kesimpulan utama adalah, dengan menaikkan durasi camshaft akan menurunkan torsi secara rata-rata dari putaran rendah hingga putaran tinggi. Namun camshaft durasi tinggi akan efektif digunakan pada putaran tinggi karena dapat meningkatkan nilai torsi.

\section{B. Analisa Grafik Daya vs Putaran}

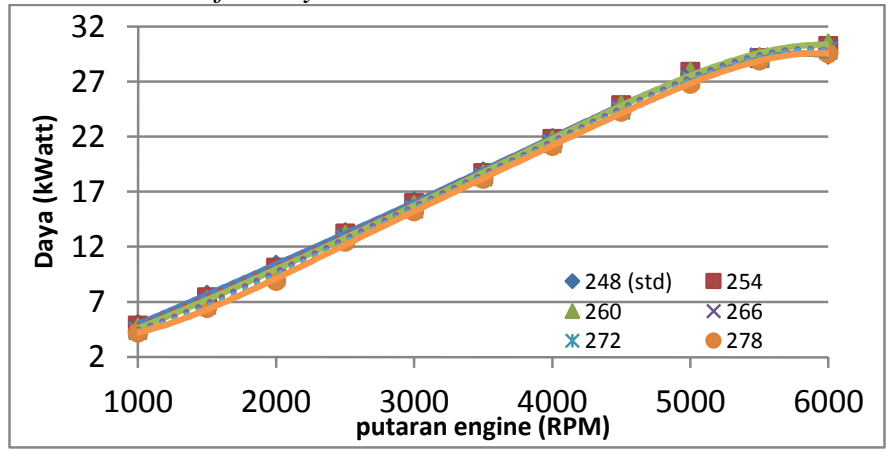

Gambar 13. Grafik Daya vs rpm hasil simulasi

Berdasarkan Gambar 13, semakin meningkatnya putaran engine, daya yang dihasilkan semakin meningkat. Karena daya merupakan fungsi torsi, maka daya juga akan mengalami penurunan pada putaran engine tertentu. Namun pada grafik, daya masih mampu melawan mechanical friction sehingga belum terlihat penurunannya hingga putaran $6000 \mathrm{rpm}$.
Trendline yang terbentuk dari masing-masing variasi durasi camshaft relatif sama, yaitu trendline terus meningkat dari putaran 1000 hingga $6000 \mathrm{rpm}$. Dari diatas, jika peningkatan daya dirata-rata maka camshaft dengan durasi $260^{\circ}$ menghasilkan persentase kenaikan paling tinggi dari camshaft standar yang bernilai $248^{\circ}$ pada rentang putaran tinggi mulai 4000-6000 rpm. Dimana persentase kenaikan yang terjadi adalah $1.173 \%$. Maka dapat disimpulkan bahwa dengan menaikkan durasi camshaft menjadi $260^{\circ}$ akan menghasilkan daya yang lebih baik dari daya yang dihasilkan oleh camshaft standar.

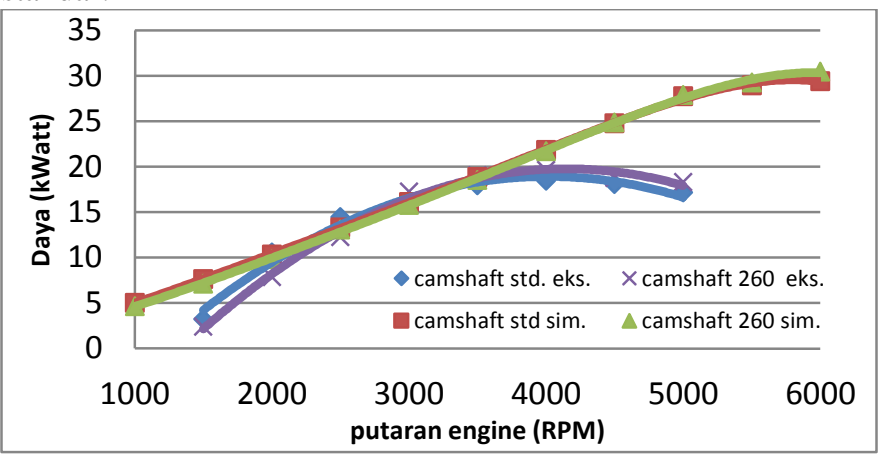

Gambar 14. Grafik Daya vs rpm hasil simulasi dan eksperimen

Dari Gambar 14 dapat dilihat bahwa terjadi selisih nilai daya antara hasil eksperimen dengan simulasi. Faktor penyebabnya pun diakibatkan oleh hal yang sama dengan penjelasan pada pembahasan torsi diatas. Grafik diatas menunjukkan bahwa simulasi menghasilkan daya yang lebih besar daripada eksperimen. Selain itu dengan memodifikasi camshaft menjadi $260^{\circ}$ akan menghasilkan daya yang lebih besar pada putaran tinggi, namun daya menurun pada putaran rendah. Ini terjadi baik pada simulasi maupun eksperimen. Daya terbesar simulasi terjadi pada putaran $6000 \mathrm{rpm}$ dengan camshaft $260^{\circ}$ dan daya terbesar eksperimen terjadi pada putaran $4000 \mathrm{rpm}$ dengan durasi camshaft $260^{\circ}$.

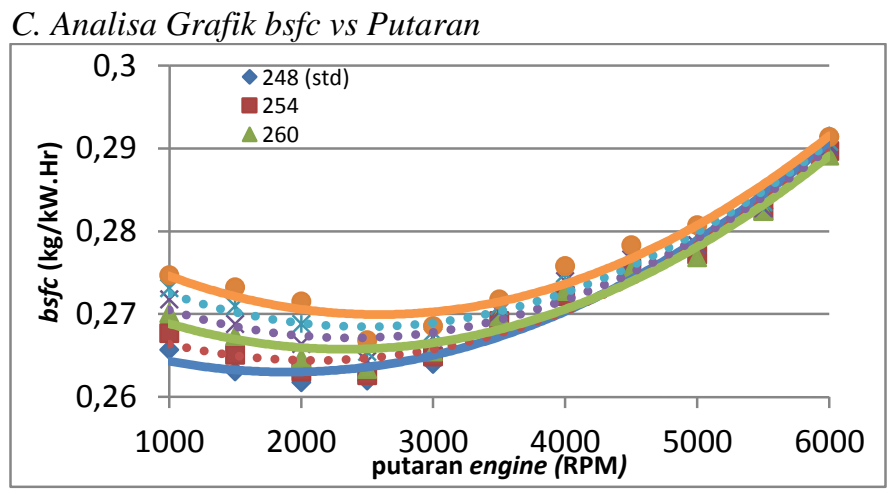

Gambar 15. Grafik bsfc vs rpm hasil Simulasi

Dari Gambar 15 diatas, pada putaran 4000 - $6000 \mathrm{rpm}$ penurunan $b s f c$ dirata-rata maka camshaft dengan durasi $260^{\circ}$ menghasilkan persentase penurunan paling besar dari camshaft standar yang bernilai $248^{\circ}$. Dimana persentase penurunan yang terjadi adalah $0.252 \%$. Secara umum konsumsi bahan bakar spesifik pada putaran rendah ke putaran tinggi akan mengalami penurunan hingga putaran tertentu akan meningkat kembali. Hal ini disebabkan karena $b s f c$ merupakan fungsi dari daya dan torsi. Pada durasi $260^{\circ}$ 
menghasilkan $b s f c$ yang rendah karena pada putaran 5000 rpm, bahan bakar yang mengalir lebih sedikit dan daya yang dihasilkan juga relatif lebih besar, sehingga bsfc yang dihasilkan nilainya kecil.

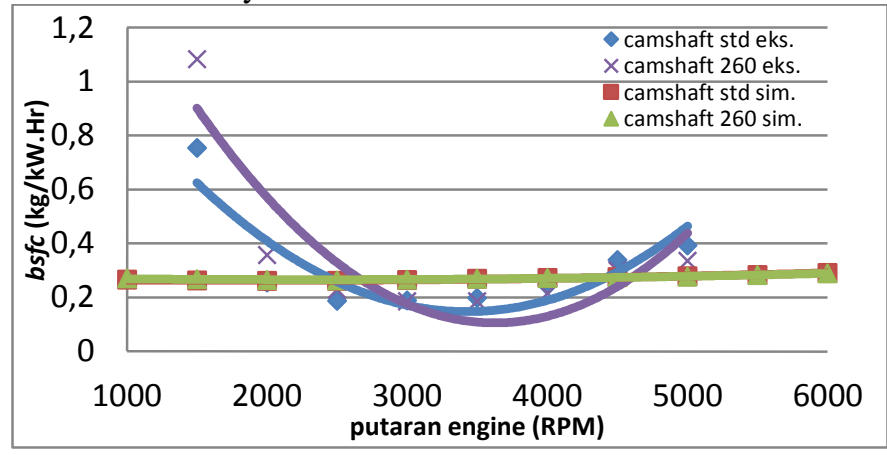

Gambar 16. Grafik bsfc vs rpm hasil Simulasi dan eksperimen

Dari Gambar 16 dapat dilihat bahwa terjadi selisih nilai $b s f c$ antara simulasi dengan eksperimen. Grafik diatas menunjukkan bahwa simulasi menghasilkan $b s f c$ yang lebih besar daripada eksperimen. Karena $b s f c$ merupakan fungsi daya, maka selisih nilai $b s f c$ dari simulasi dan eksperimen disebabkan oleh hal yang sama dengan daya, yaitu disebabkan oleh beberapa faktor, baik dari faktor software simulasi maupun, engine, alat ukur maupun pembacaan alat ukurSelain itu dengan memodifikasi camshaft menjadi $260^{\circ}$ akan menghasilkan $b s f c$ yang lebih tinggi pada putaran rendah, namun $b s f c$ menurun pada putaran tinggi. Ini terjadi baik pada simulasi maupun eksperimen. Pada putaran tinggi, $b s f c$ terendah simulasi pada $2000 \mathrm{rpm}$ dengan camshaft $248^{\circ}$ dan $b s f c$ terendah eksperimen pada putaran $3000 \mathrm{rpm}$ dengan camshaft $260^{\circ}$.

\section{Analisa Grafik Efisiensi Volumetris vs Putaran}

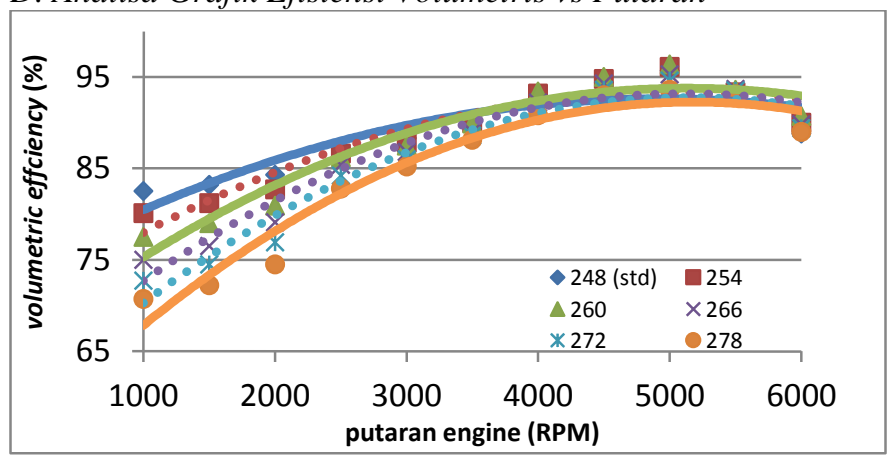

Gambar 17. Grafik Efisiensi Volumetris vs rpm hasil Simulasi

Dari Gambar 17 dapat dilihat trendline kenaikan efisiensi volumetris terjadi mulai dari putaran engine 1500 rpm. Grafik diatas menunjukkan bahwa dengan menggunakan camshaft durasi rendah menghasilkan efisiensi volumetris yang lebih besar pada putaran rendah dan dengan menggunakan camshaft durasi tinggi menghasilkan efisiensi volumetris yang lebih besar pada putaran tinggi. Pada putaran $5000 \mathrm{rpm}$, nilai tertinggi dari efisiensi volumetris terjadi pada camshaft durasi $260^{\circ}$ dibandingkan dengan camshaft durasi $248^{\circ}$. Faktor ini disebabkan oleh aliran dinamik fluida yang masuk kedalam silinder, durasi overlap, dan tekanan kompresi dinamis yang terjadi di setiap putaran mesin. Dengan durasi camshaft yang bertambah besar dari standar, dengan lobe separation angel (LSA) dan lobe lift yang sama menyebabkan perbedaan durasi overlapping. Bertambahnya overlapping menyebabkan waktu interaksi antar intake port dan exhaust port berlangsung lebih lama, hal ini mempengaruhi suhu udara yang masuk kedalam ruang bakar. Terjadi kenaikan suhu pada udara yang kemudian berpengaruh pada flowrate udara yang masuk mengakibatkan terjadi perubahan pada efisiensi volumetris. Pada putaran tinggi hal ini tidak banyak berpengaruh karena kecepatan udara bertambah tinggi berbanding terbalik dengan durasi siklus pembakaran dan overlapping. Dengan durasi yang bertambah, pengaruh pada putaran tinggi yaitu menambah pasokan udara yang masuk kedalam silinder mengakibatkan bertambahnya efisiensi volumetris.

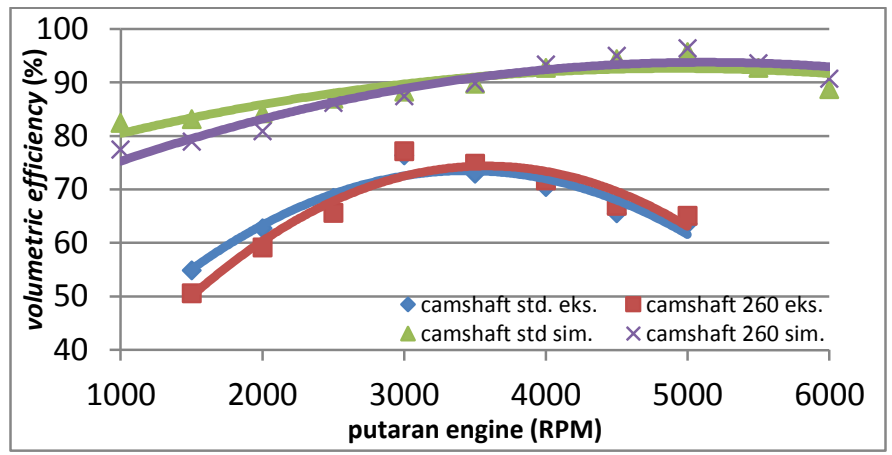

Gambar 18. Grafik Efisiensi Volumetris vs rpm hasil Simulasi dan Eksperimen

Dari Gambar 18 dapat dilihat bahwa terjadi selisih nilai efisiensi volumetris antara hasil simulasi dengan eksperimen. Grafik diatas menunjukkan bahwa simulasi menghasilkan efisiensi volumetris yang lebih besar daripada eksperimen. Selain itu dengan memodifikasi camshaft menjadi $260^{\circ}$ akan menghasilkan efisiensi volumetris yang lebih tinggi pada putaran tinggi, namun efisiensi volumetris menurun pada putaran rendah. Ini terjadi baik pada simulasi maupun eksperimen. Efisiensi volumetris tertinggi simulasi pada 5000 rpm dengan camshaft $260^{\circ}$ dan efisiensi volumetris terbesar eksperimen pada $3000 \mathrm{rpm}$ dengan camshaft $260^{\circ}$.

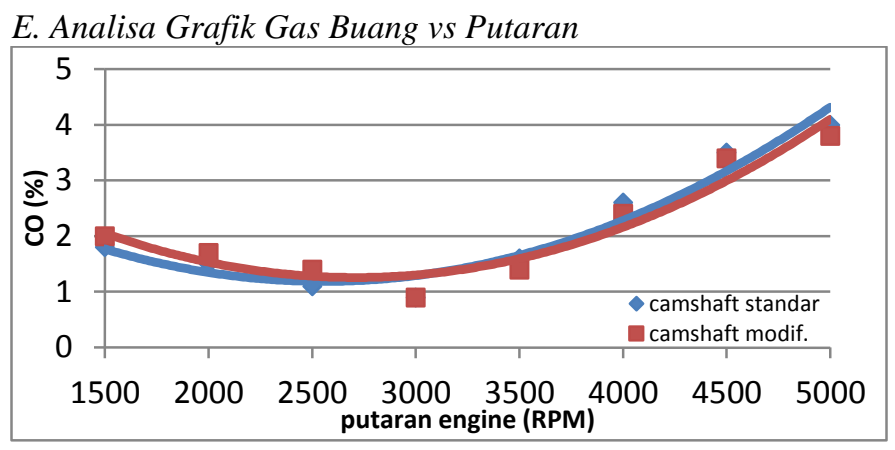

Gambar 19. Grafik CO vs rpm Durasi Camshaft Standar dan Modifikasi hasil Eksperimen 


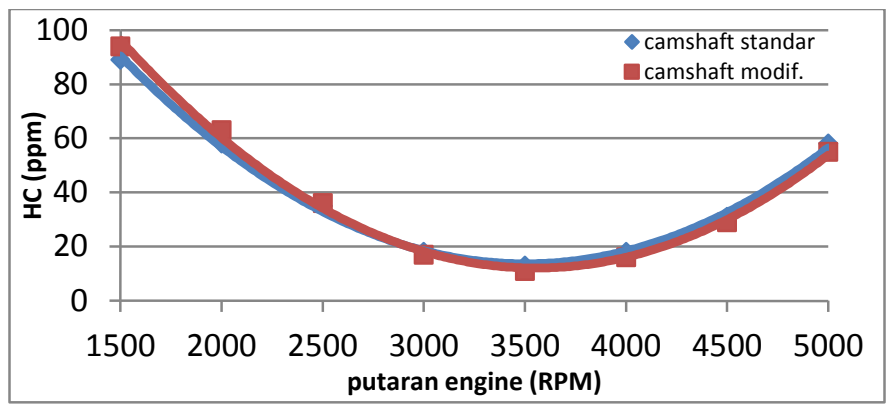

Gambar 20. Grafik HC vs rpm Durasi Camshaft Standar dan Modifikasi hasil Eksperimen

Gambar 20 dan 21 menunjukkan grafik gas buang HC dan $\mathrm{CO}$, dari grafik tersebut dapat diketahui bahwa camshaft standar memiliki kadar $\mathrm{HC}$ dan $\mathrm{CO}$ yang lebih tinggi dari camshaft modifikasi pada putaran 3000 - $5000 \mathrm{rpm}$. Kondisi grafik diatas memiliki trendline yang serupa, yaitu dengan camshaft standar dan modifikasi membentuk grafik parabolik terbuka kebawah seiring naiknya putaran engine. Nilai HC tertinggi pada $1500 \mathrm{rpm}$ dengan camshaft modifikasi, dan CO tertinggi pada $2000 \mathrm{rpm}$ dengan camshaft standar.

Pada temperatur engine yang semakin tinggi, proses atomizing menjadi lebih baik. Hal ini ditunjukkan dengan menurunnya kandungan $\mathrm{HC}$ pada camshaft modifikasi hingga putaran $3500 \mathrm{rpm}$, hal ini karena camshaft modifikasi menghasilkan temperatur engine yang rendah, kemudian mengalami kenaikan hingga putaran 5000 rpm. Emisi CO cenderung timbul pada temperatur pembakaran yang tinggi. Jumlah oksigen dalam campuran juga sangat menentukan besar CO yang dihasilkan, mengingat kurangnya oksigen dalam campuran akan mengakibatkan karbon bereaksi tidak sempurna dengan oksigen (sehingga terbentuk $\mathrm{CO}$ ).

\section{KESIMPULAN}

Beberapa kesimpulan yang bisa diambil dari penelitian ini adalah sebagai berikut:

1. Dari seluruh penelitian menggunakan metode simulasi dan metode eksperimen terhadap durasi camshaft, dapat diketahui bahwa camshaft durasi rendah menghasilkan unjuk kerja yang lebih besar pada putaran rendah namun buruk pada putaran tinggi, dan sebaliknya camshaft durasi tinggi menghasilkan unjuk kerja yang baik pada putaran tinggi namun buruk pada putaran rendah.

2. Hasil simulasi perbandingan unjuk kerja engine SINJAI 650 cc SOHC port fuel injection yang terbaik menggunakan durasi camshaft $260^{\circ}$, dengan peningkatan torsi $0.908 \%$, daya $0.908 \%$, bmep $0.908 \%$, efisiensi thermal $0.626 \%$, efisiensi volumetris $1.003 \%$ dan penurunan $b s f c 0.252 \%$ dari camshaft standar pada putaran tinggi rentang 4000-6000 RPM.

3. Hasil eksperimen perbandingan unjuk kerja engine SINJAI 650 cc SOHC port fuel injection menggunakan camshaft $260^{\circ}$, dengan peningkatan torsi $5.53 \%$, daya $5.53 \%$, bmep $5.53 \%$, efisiensi thermal $14.58 \%$, efisiensi volumetris $2.04 \%$ dan penurunan bsfc $17.905 \%$ dari camshaft standar pada putaran tinggi rentang 3000-5000 RPM.
4. Hasil perbandingan simulasi engine SINJAI $650 \mathrm{cc}$ SOHC port injection menghasilkan unjuk kerja lebih baik dari hasil eksperimen pada durasi camshaft standar, dengan selisih torsi $17 \%$, daya $17 \%$, bmep $17 \%$, efisiensi thermal $12.3 \%$, efisiensi volumetris $33 \%$ dan $b s f c$ $17.91 \%$ dari hasil eksperimen pada putaran tinggi rentang 3000-5000 RPM.

\section{DAFTAR PUSTAKA}

[1] Sungkono Kawano, D. 2011. Motor Bakar Torak (Diesel). Surabaya: ITS Press.

[2] Sungkono Kawano, D. 2011. Motor Bakar Torak (Bensin). Surabaya: ITS Press

[3] Graham Bell, A. 1981. Four Stroke Performance Tuning in Theory and Practice. England: Haynes Publishing Group 